\title{
Article \\ A Maritime Cloud-Detection Method Using Visible and Near-Infrared Bands over the Yellow Sea and Bohai Sea
}

\author{
Yun-Jeong Choi ${ }^{1,+}$, Hyun-Ju Ban ${ }^{1,+}$, Hee-Jeong Han ${ }^{2}\left(\mathbb{D}\right.$ and Sungwook Hong ${ }^{1,3, *(D)}$ \\ 1 Department of Environment, Energy and Geoinfomatics, Sejong University, Seoul 05006, Korea; \\ choiyun@sju.ac.kr (Y.-J.C.); hjban@sju.ac.kr (H.-J.B.) \\ 2 Korea Ocean Satellite Center, Korea Institute of Ocean Science and Technology, Busan 49111, Korea; \\ han77@kiost.ac.kr \\ 3 DeepThoTh, Co., Ltd., Seoul 05006, Korea \\ * Correspondence: sesttiya@sejong.ac.kr; Tel.: +82-2-6935-2430 \\ + These authors contributed equally to this work.
}

Citation: Choi, Y.-J.; Ban, H.-J.; Han, H.-J.; Hong, S. A Maritime CloudDetection Method Using Visible and Near-Infrared Bands over the Yellow Sea and Bohai Sea. Remote Sens. 2022, 14, 793. https://doi.org/10.3390/ rs14030793

Academic Editors: Jungho Im and YongHoon Kim

Received: 27 December 2021

Accepted: 6 February 2022

Published: 8 February 2022

Publisher's Note: MDPI stays neutral with regard to jurisdictional claims in published maps and institutional affiliations.

Copyright: (c) 2022 by the authors. Licensee MDPI, Basel, Switzerland. This article is an open access article distributed under the terms and conditions of the Creative Commons Attribution (CC BY) license (https:// creativecommons.org/licenses/by/ $4.0 /)$.

\begin{abstract}
Accurate cloud-masking procedures to distinguish cloud-free pixels from cloudy pixels are essential for optical satellite remote sensing. Many studies on satellite-based cloud-detection have been performed using the spectral characteristics of clouds in terms of reflectance and temperature. This study proposes a cloud-detection method using reflectance in four bands: $0.56 \mu \mathrm{m}, 0.86 \mu \mathrm{m}$, $1.38 \mu \mathrm{m}$, and $1.61 \mu \mathrm{m}$. Methodologically, we present a conversion relationship between the normalized difference water index (NDWI) and the green band in the visible spectrum for thick cloud detection using moderate-resolution imaging spectroradiometer (MODIS) observations. NDWI consists of reflectance at the 0.56 and $0.86 \mu \mathrm{m}$ bands. For thin cloud detection, the 1.38 and $1.61 \mu \mathrm{m}$ bands were applied with empirically determined threshold values. Case study analyses for the four seasons from 2000 to 2019 were performed for the sea surface area of the Yellow Sea and Bohai Sea. In the case studies, the comparison of the proposed cloud-detection method with the MODIS cloud mask (CM) and Cloud-Aerosol Lidar and Infrared Pathfinder Satellite Observation data indicated a probability of detection of 0.933 , a false-alarm ratio of 0.086 , and a Heidke Skill Score of 0.753 . Our method demonstrated an additional important benefit in distinguishing clouds from sea ice or yellow dust, compared to the MODIS CM products, which usually misidentify the latter as clouds. Consequently, our cloud-detection method could be applied to a variety of low-orbit and geostationary satellites with $0.56,0.86,1.38$, and $1.61 \mu \mathrm{m}$ bands.
\end{abstract}

Keywords: cloud detection; cloud mask; NDWI; visible; near-infrared; ocean color; MODIS

\section{Introduction}

Cloud information is significant for weather analysis, climate change, and other shortterm environmental issues [1,2]. Satellite remote-sensing plays a crucial role in monitoring the Earth's surface and atmosphere. For remote sensing of the Earth's surface, clouds pose an obstacle, as they cover a large area of the Earth's surface and need to be effectively removed. Thus, cloud detection is a preliminary prerequisite step and one of the most difficult problems in satellite remote-sensing $[3,4]$.

Many studies on satellite-based cloud detection have been performed which measured the spectral characteristics of clouds, such as high reflectance and low temperature in the visible (VIS), near-infrared (NIR) [5], shortwave infrared (SWIR) [6], and longwave infrared (LWIR) [7-9] bands. Brightness temperature difference (BTD) methods are also used for cloud detection in satellite remote sensing. For example, a BTD between 11 and $12 \mu \mathrm{m}$ is useful for detecting stratiform clouds such as cirrus [10]. The BTD between $3.9 \mu \mathrm{m}$ and $11 \mu \mathrm{m}$ is useful for detecting low-level water clouds in most scenes and partial or thin cloud coverage at night [10]. Furthermore, there have been a number of studies to accurately identify clouds over ice and water using the SWIR band [11], mid-wave infrared 
(IR) bands [12], VIS bands, and NIR bands [13]. Recently, cloud detection has been explored through various deep learning techniques, including convolutional neural networks $[14,15]$, machine learning methods, such as the support vector machine [16] and random forest method [17], as well as classical cloud detection algorithms including threshold-based technique [18] and dynamic threshold [19].

Traditionally, cloud-detection methods based on simple VIS and IR window threshold values have been widely applied $[20,21]$ in many projects, such as the International Satellite Cloud Climatology Project, Clouds from the Advanced Very High Resolution Radiometer (AVHRR; National Oceanic and Atmospheric Administration), and AVHRR Processing scheme Over cLouds, Land and Ocean [22], because clouds are generally characterized by a higher reflectance and lower temperature than the underlying Earth's surface [23].

In addition, NASA's earth-observing system anchored several active and passive satellite sensors with unprecedented observation capabilities in a formation called the afternoon constellation or the A-Train [24]. The A-Train has been regarded as among the most accurate sensors for detecting clouds globally [25]. The Cloud-Aerosol Lidar and Infrared Pathfinder Satellite Observation (CALIPSO) also provides global cloud and aerosol data with the Cloud-Aerosol Lidar with Orthogonal Polarization (CALIOP) onboard CALIPSO, observing the backscattered signal at 0.532 and $1.064 \mu \mathrm{m}$ bands [26]. The Moderate Resolution Imaging Spectroradiometer (MODIS) cloud mask (CM) product has been the most fundamental of the MODIS land, ocean, and atmosphere products [27,28]. This is because of its long temporal record, wide swath and sampling, and broad spectral range [25]. The MODIS CM was established based on global analyses using calibrated MODIS radiance data in the VIS and IR bands [28].

The MODIS products provide the cloud detection product referred to as MOD35 [29,30], relying on a series of sequential tests on reflectance $(R)$ and radiances (or brightness temperatures $(B T)$ ) in the instrument field of view (FOV). The MOD35 CM includes many cloud test thresholds of reflectance, such as $R_{0.67 \mu \mathrm{m}}$ and $R_{0.87 \mu \mathrm{m}}$ for thick low and high clouds, $R_{1.38 \mu \mathrm{m}}$ for high thin and thick clouds, and $R_{1.6 \mu \mathrm{m}}$ for low and high clouds over snow. Additionally, the MOD35 CM includes many IR cloud test thresholds; such as $B T_{11 \mu \mathrm{m}}$ for oceans, $B T_{13.9 \mu \mathrm{m}}$ for all nonpolar regions, $B T$ difference $(B T D) B T_{6.7 \mu \mathrm{m}}$ for all polar regions except Antarctic night, surface temperatures at $B T_{11 \mu \mathrm{m}}, B T_{11 \mu \mathrm{m}-12 \mu \mathrm{m}}$ for all

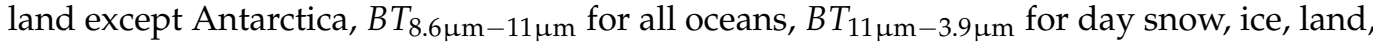

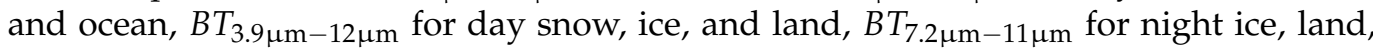
and ocean, and $B T_{8.6 \mu \mathrm{m}-7.2 \mu \mathrm{m}}$ for night ocean [31]. The thresholds of the MODIS cloud detection algorithm vary depending on the region or conditions [31-33]. Consequently, the MOD35 CM products provide a variety of information on cloud mask, sun glint, snow/ice, heavy aerosol, thin cirrus, shadow, and information on whether it is day/night and if the clouds are present over land and water [30]. However, the problem with the MODIS CM is that it misidentifies snow $[30,32,34]$ and ice [35] as clouds.

The objective of this study is to explore a method for detecting daytime clouds over the ocean. We selected the Yellow Sea and Bohai Sea as the study areas. We used only four channels of MODIS sensors in the VIS and NIR spectral bands. We verified our method for several case studies by comparing it with MODIS CM. Figure 1 shows the MODIS red-green-blue (RGB) image using 0.56, 0.86, and $1.6 \mu \mathrm{m}$ bands [36] and the MODIS CM (MOD35_L2) over the Yellow Sea and Bohai Sea on 3 January 2013, 03:15 UTC. The current MODIS CM misidentifies sea ice over the Bohai Sea as clouds (pink). 
(a)

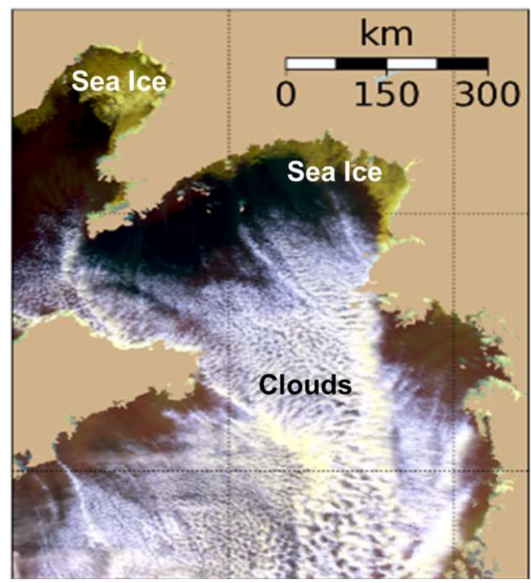

(b)

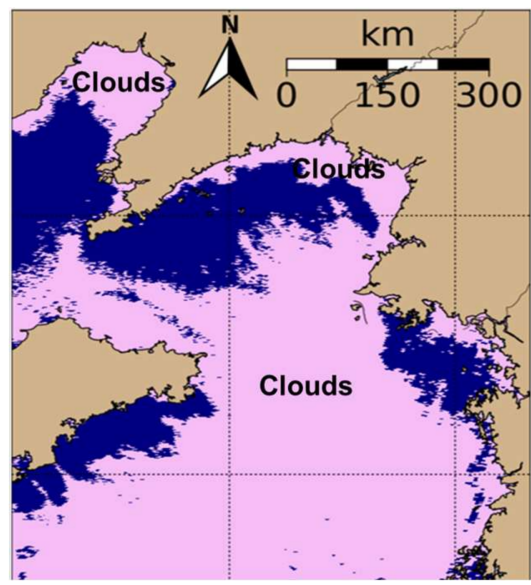

Figure 1. Example of misidentifying sea ice as clouds by MODIS CM. (a) MODIS RGB image using 0.56, 0.86, and 1.6 um bands [36]; (b) MODIS CM (MOD35_L2) on 3 January 2013, 03:15 UTC.

\section{Methods}

\subsection{Cloud Detection Method}

This study used four bands-one VIS $(0.56 \mu \mathrm{m}$, green band) and three NIR $(0.86,1.38$, and $1.61 \mu \mathrm{m}$ ) bands for cloud detection. For thick cloud detection, we used the normalized difference water index (NDWI), a satellite-derived index from the combination of the green band and NIR band [37,38]. The green and NIR bands of the Landsat Thematic Mapper were used to produce the NDWI [39]. The water surface reflects the most radiance in VIS bands but absorbs strongly in NIR bands [38]; thus, NDWI is sensitive to liquid water changes.

This study proposes a relationship between NDWI and the $0.56 \mu \mathrm{m}$ band for cloud detection over the sea surface. Our thick cloud detection method consists of the following steps:

First, we chose cloud pixels from the MODIS RGB image. Figure 2 presents an example of Terra MODIS RGB images on 1 June 2017, 02:15 UTC used in this study.

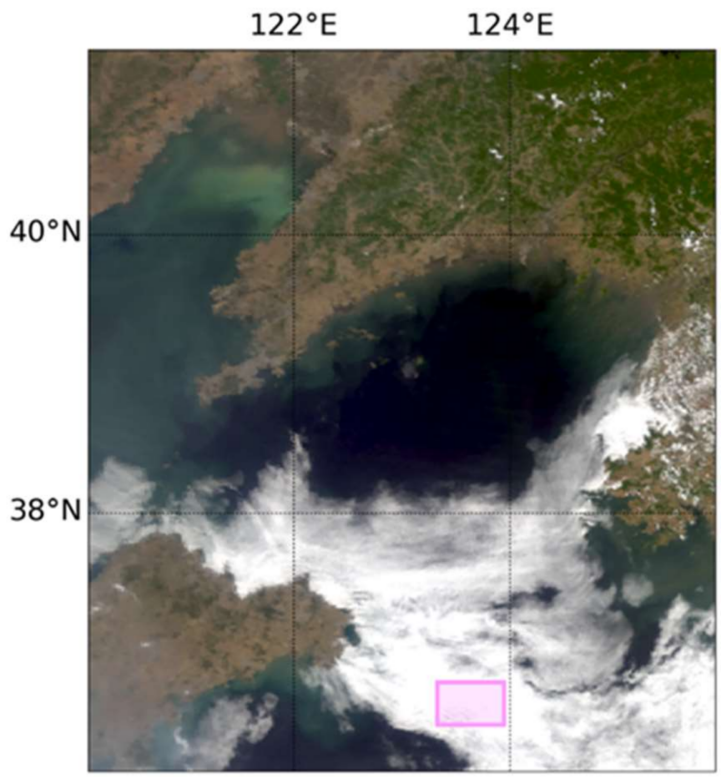

Figure 2. MODIS RGB image on 1 June 2017, 02:15 UTC and the selection of clouds. The pink box indicates clouds. 
Second, we adopted the NDWI. In this study, $N D W I_{o b s}$ indicated the NDWI values calculated using the green and NIR bands of MODIS data as follows [37]:

$$
N D W I_{o b s}=\frac{R_{0.56 \mu \mathrm{m}}-R_{0.86 \mu \mathrm{m}}}{R_{0.56 \mu \mathrm{m}}+R_{0.86 \mu \mathrm{m}}}
$$

Here, $N D W I_{o b s}$ is the NDWI observed from the MODIS reflectance data. $R_{0.56 \mu \mathrm{m}}$ and $R_{0.86 \mu \mathrm{m}}$ are the reflectances of 0.56 and $0.86 \mu \mathrm{m}$, respectively.

Third, we presented $N D W I_{\text {cal }}$, which is a regression relationship fitting the distribution of the observed pixels in the NDWI-R $0.56 \mu \mathrm{m}$ plane. Herein, NDWI $I_{\text {cal }}$ was defined in a quadratic form as follows:

$$
N D W I_{c a l}=a_{0}+a_{1} \cdot R_{0.56 \mu \mathrm{m}}+a_{2} \cdot R_{0.56 \mu \mathrm{m}}^{2}
$$

where NDWI $I_{c a l}$ is the NDWI calculated from reflectance data of the MODIS $0.56 \mu \mathrm{m}$ band in the NDWI-R $0.56 \mu \mathrm{m}$ plane. $a_{0}, a_{1}$, and $a_{2}$ are regression coefficients.

Real cloud pixels were distributed around the $N D W I_{\text {cal }}$ curve (Equation (2)) (see Figure 5). Thus, we determined the threshold values of the NDWI for cloud detection using the standard deviation $(\sigma)$ of the Gaussian distribution of cloud pixels around the $N D W I_{\text {cal }}$ curve (Equation (2)), for the area marked by the pink box (in Figure 2), as follows:

$$
N D W I_{c a l}-k \cdot \sigma_{1}<N D W I_{o b s}<N D W I_{c a l}+k \cdot \sigma_{1}
$$

where $k$ is the coefficient empirically determined from the histogram distribution of the pixels for clouds. In this study, we set $k=1 . \sigma_{1}$ is the standard deviation of the histogram distribution of pixels in the cloud.

Fourth, the method based on Equations (1)-(3) without other band observations often misidentified thin clouds as non-cloud pixels. Thus, we combined the NDWI-based method for thick cloud detection with the threshold methods using 1.38 and $1.61 \mu \mathrm{m}$ bands for thin cloud detection. The $1.38 \mu \mathrm{m}$ band is commonly called the "cirrus band" because of its sensitivity to water vapor above and within the cirrus $[40,41]$ and is therefore useful for optically thin cirrus detection [42-46]. The $1.61 \mu \mathrm{m}$ band has a lower reflection and an absorption effect on cloud ice particles [41]. This $1.61 \mu \mathrm{m}$ band is often used in the form of Normalized Difference Snow Index [37-39].

We applied thresholds to the reflectances $R_{1.38 \mu \mathrm{m}}$ and $R_{1.61 \mu \mathrm{m}}$ at 1.38 and $1.61 \mu \mathrm{m}$ bands, respectively, as:

$$
R_{1.38 \mu \mathrm{m}}>\sigma_{2} \text { and } R_{1.61 \mu \mathrm{m}}>\sigma_{3}
$$

where $\sigma_{2}$ and $\sigma_{3}$ are the threshold values empirically determined from the histogram distributions of the pixels for thin clouds at the 1.38 and $1.61 \mu \mathrm{m}$ bands, respectively. For this study, we used $\sigma_{2}=0.006$ and $\sigma_{3}=0.04$, which were chosen from statistical comparison results (the best values of correlation coefficient (CC) and root mean square error (RMSE)) between MODIS CM and our CM including 1.38 and $1.61 \mu \mathrm{m}$ bands.

\subsection{Comparison}

The proposed cloud detection method is compared with data from MOD35_L2. MODIS detected various types of clouds, including thin cirrus clouds. The statistical analysis of the proposed cloud detection algorithm with MODIS35_L2 was performed using the probability of detection (POD), false-alarm ratio (FAR), and Heidke Skill Score (HSS) as follows:

$$
\begin{gathered}
\mathrm{POD}=\frac{A}{A+C} \\
\mathrm{FAR}=\frac{B}{B+D} \\
\mathrm{HSS}=\frac{2(A D-B C)}{(A+C)(C+D)+(A+B)(B+D)}
\end{gathered}
$$


where $A$ indicates that both the proposed CM and MODIS CM indicate a cloud pixel; $B$ implies that the proposed CM is a cloud pixel, but MODIS CM is not a cloud pixel; $C$ infers that the proposed CM is not a cloud pixel, but MODIS CM is a cloud pixel; and D infers that both CMs are not clouds. The POD and HSS are close to 1 , and the FAR is close to 0 for the best possible and perfect detections [47]. The contingency tables are presented in Table 1.

Table $1.2 \times 2$ contingency table.

\begin{tabular}{ccc}
\hline CMs & MODIS CM =1 (Yes) & MODIS CM = 0 (No) \\
\hline Proposed CM $=1($ Yes $)$ & $A$ & $B$ \\
Proposed $C M=0(\mathrm{No})$ & $C$ & $D$ \\
\hline
\end{tabular}

Figure 3 shows a flowchart of the cloud detection method presented in this study. First, the MODIS calibrated radiance data (MOD021KM) at the VIS and NIR bands were converted to reflectance values. Next, the cloud and no-cloud flags were retrieved using the proposed cloud detection algorithm, using the NDWI, the green band, $1.38 \mu \mathrm{m}$, and $1.61 \mu \mathrm{m}$ band reflectances. Finally, our CM method was compared with MODIS CM.

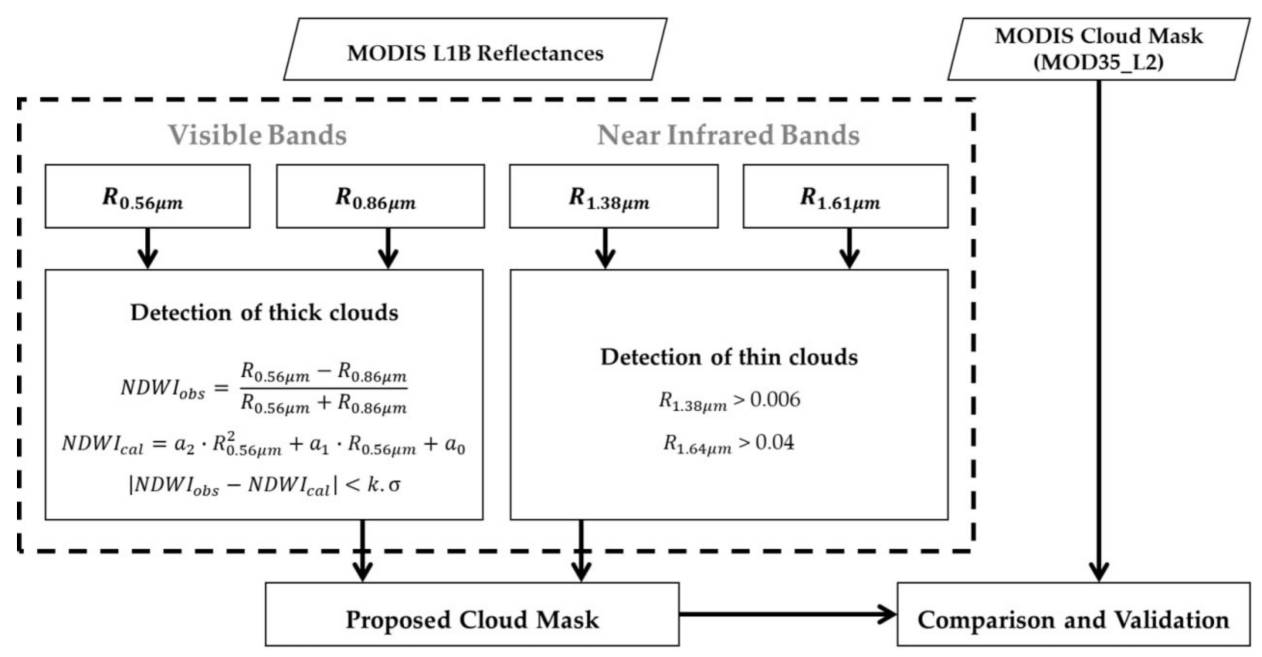

Figure 3. Flowchart of the proposed cloud detection method.

\section{Study Area and Data}

\subsection{MODIS}

In this study, we used data from the MODIS onboard Terra satellite to develop a cloud detection method. The MODIS sensor has 36 spectral bands from VIS $(0.4 \mu \mathrm{m})$ to IR $(14 \mu \mathrm{m})$. This study selected four MODIS bands; $0.56 \mu \mathrm{m}$ (band 4), $0.86 \mu \mathrm{m}$ (band 2), $1.64 \mu \mathrm{m}$ (band 6), and $1.38 \mu \mathrm{m}$ (band 26). MODIS CM (MOD35_L2) was used to compare the results of the cloud detection results proposed in this study. This study used "cloudy" and "probably cloudy" as a classification of cloudiness in MODIS CM based on the unobstructed FOV quality flags ("cloudy," "probably cloudy," "probably clear," and "confident clear") from the MODIS CM.

We chose the Yellow Sea and Bohai Sea regions as the study area for the cloud detection method development because sea ice and clouds often coexist in this region during winter. The ice crystals of clouds have properties similar to those of ice over the sea and hence are difficult to distinguish, making this region suitable for testing the cloud detection algorithm. Figure 4 displays the study area (in the red box) selected for cloud detection in the Yellow Sea and the Bohai Sea. Table 2 summarizes the 2000 to 2019 case studies used to develop and compare a cloud detection method. 


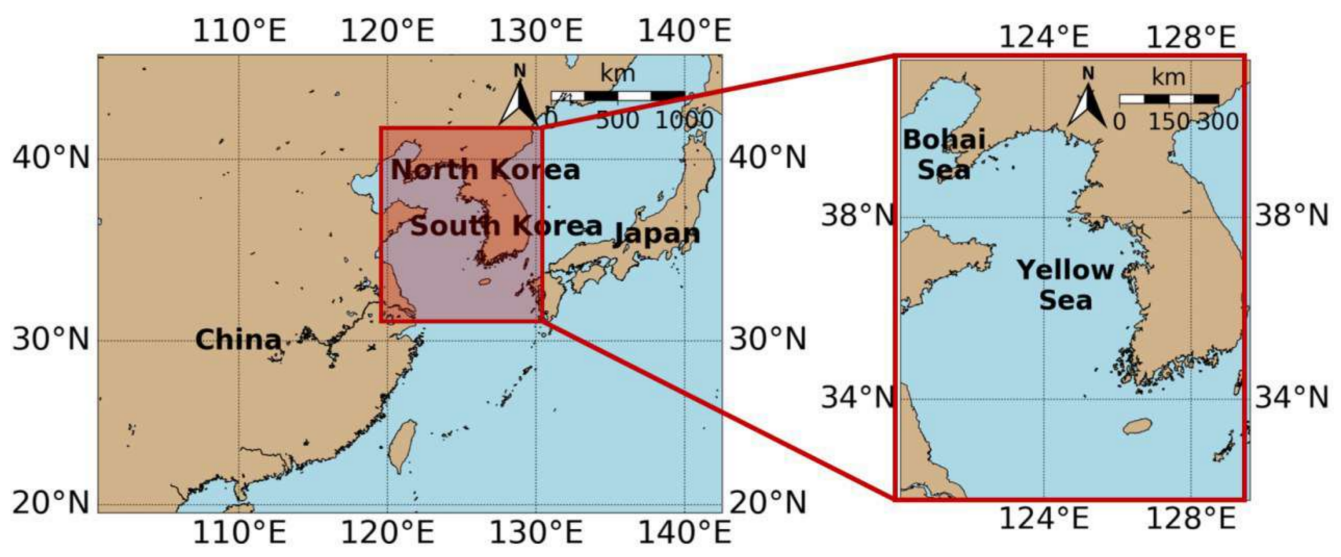

Figure 4. Study area including the Yellow Sea and Bohai Sea.

Table 2. Case studies used in this study.

\begin{tabular}{|c|c|c|}
\hline Year & Date & Purpose \\
\hline 2000 & $\begin{array}{c}\text { May } 20 \text { (03:00 UTC), July } 27 \text { (02:35 UTC), October } 02 \\
\text { (03:05 UTC) }\end{array}$ & Test, Comparison \\
\hline 2001 & $\begin{array}{c}\text { January } 01 \text { (02:45 UTC), April } 02 \text { (02:25 UTC), July } 05 \\
\text { (02:35 UTC), October } 11 \text { (02:20 UTC) }\end{array}$ & Test, Comparison \\
\hline 2002 & $\begin{array}{c}\text { January } 08 \text { (02:10 UTC), April } 21 \text { (02:15 UTC), July } 03 \\
\text { (02:10 UTC), October } 07 \text { (02:10 UTC) }\end{array}$ & Test, Comparison \\
\hline 2003 & $\begin{array}{c}\text { January } 02 \text { (02:15 UTC), April } 08 \text { (02:15 UTC), July } 07 \\
\text { (02:50 UTC), October } 08 \text { (02:20 UTC) }\end{array}$ & Test, Comparison \\
\hline 2004 & $\begin{array}{c}\text { January } 01 \text { (02:40 UTC), May } 22 \text { (02:50 UTC), July } 22 \\
\text { (02:20 UTC), October } 01 \text { (02:25 UTC) }\end{array}$ & Test, Comparison \\
\hline 2005 & $\begin{array}{c}\text { January } 01 \text { (02:50 UTC), May } 06 \text { (02:20 UTC), July } 09 \\
\text { (02:20 UTC), October } 29 \text { (02:20 UTC) }\end{array}$ & Test, Comparison \\
\hline 2006 & $\begin{array}{c}\text { January } 15 \text { (02:30 UTC), April } 19 \text { (02:45 UTC), July } 15 \\
\text { (02:50 UTC), October } 23 \text { (02:25 UTC) }\end{array}$ & Test, Comparison \\
\hline 2007 & $\begin{array}{c}\text { January } 04 \text { (02:20 UTC), April } 13 \text { (02:50 UTC), June } 25 \\
\text { (02:45 UTC), October 06 (02:50 UTC) }\end{array}$ & Test, Comparison \\
\hline 2008 & $\begin{array}{c}\text { January } 03 \text { (02:45 UTC), April } 15 \text { (02:50 UTC), July } 26 \\
\text { (02:15 UTC), October } 17 \text { (02:45 UTC) }\end{array}$ & Test, Comparison \\
\hline 2009 & $\begin{array}{c}\text { January } 02 \text { (02:15 UTC), March } 03 \text { (02:40 UTC), July } 29 \\
\text { (02:15 UTC), October } 11 \text { (02:50 UTC) }\end{array}$ & Test, Comparison \\
\hline 2010 & $\begin{array}{c}\text { January } 05 \text { (02:15 UTC), April } 27 \text { (02:15 UTC), August } 11 \\
\text { (02:50 UTC), October 07 (02:45 UTC) }\end{array}$ & Test, Comparison \\
\hline 2011 & $\begin{array}{c}\text { January } 06 \text { (02:25 UTC), April } 17 \text { (02:45 UTC), August } 27 \\
\text { (20:20 UTC), September } 15 \text { (02:50 UTC) }\end{array}$ & Test, Comparison \\
\hline 2012 & $\begin{array}{c}\text { January } 02 \text { (02:20 UTC), April } 19 \text { (02:45 UTC), August } 25 \\
\text { (02:45 UTC), October } 16 \text { (02:20 UTC) }\end{array}$ & Test, Comparison \\
\hline 2013 & $\begin{array}{c}\text { January } 04 \text { (02:20 UTC), April } 06 \text { (02:45 UTC), June } 06 \\
\text { (02:15 UTC), September } 29 \text { (02:45 UTC) }\end{array}$ & Test, Comparison \\
\hline 2014 & $\begin{array}{c}\text { January } 07 \text { (02:20 UTC), April } 29 \text { (02:20 UTC), July } 11 \\
\text { (02:15 UTC), October } 02 \text { (02:45 UTC) }\end{array}$ & Test, Comparison \\
\hline 2015 & $\begin{array}{c}\text { January } 06 \text { (02:45 UTC), April } 16 \text { (02:20 UTC), June } 12 \\
\text { (02:20 UTC), September } 12 \text { (02:40 UTC) }\end{array}$ & Test, Comparison \\
\hline 2016 & $\begin{array}{c}\text { January } 06 \text { (02:15 UTC), April } 18 \text { (02:20 UTC), August } 08 \\
\text { (02:20 UTC), October 04 (02:15 UTC) }\end{array}$ & Test, Comparison \\
\hline \multirow[t]{2}{*}{2017} & June 01 (02:15 UTC) & Method development \\
\hline & $\begin{array}{c}\text { January } 11 \text { (02:45 UTC), April } 14 \text { (02:15 UTC), July } 10 \\
\text { (02:20 UTC), October } 10 \text { (02:45 UTC) }\end{array}$ & Test, Comparison \\
\hline 2018 & $\begin{array}{c}\text { January } 05 \text { (02:50 UTC), April } 04 \text { (02:45 UTC), August } 19 \\
\text { (02:40 UTC), October 06 (02:40 UTC) }\end{array}$ & Test, Comparison \\
\hline 2019 & $\begin{array}{c}\text { January } 01 \text { (02:45 UTC), April } 07 \text { (02:45 UTC), July } 03 \\
\text { (02:50 UTC), October } 04 \text { (02:20 UTC) }\end{array}$ & Test, Comparison \\
\hline
\end{tabular}




\subsection{CALIPSO}

This study used the CALIPSO vertical feature mask (VFM) data (version 4.200 of CAL_LID_L2_01 km CLay-Standard data) with cloud layer information at a $1 \mathrm{~km}$ spatial resolution to validate the proposed CM because cloudy pixels are included in the CALIPSO data feature classification flags. To ensure spatial and temporal colocation, CALIPSO laser footprints that were found within the bounds of and acquired at nearly the same time as the MODIS image were chosen.

\section{Results}

Figure 5a displays the distribution of cloud pixels (pink color) selected in Figure 2 in the NDWI-green band plane. Cloud pixels are distributed within the range of NDWI $\leq 0$ and green band reflectance $>0.3$ in the NDWI-green band plane. Figure $5 \mathrm{~b}$ shows the relationship between NDWI and the reflectance of the green band $(0.56 \mu \mathrm{m})$ for cloud detection. The blue pixels indicate cloud pixels, including thin and thick clouds. The red line indicates the regression relationship obtained using (2). In this case, the regression coefficients $a_{0}, a_{1}$, and $a_{2}$ were calculated as $0.079,-0.4$, and 0.312 , respectively. The standard deviation value $(\sigma)$, including the uncertainty of cloud detection using the relationship between NDWI and MODIS $R_{0.56 \mu \mathrm{m}}$, was estimated to be 0.0377 using Equation (3) on 1 June 2017, 02:15 UTC.
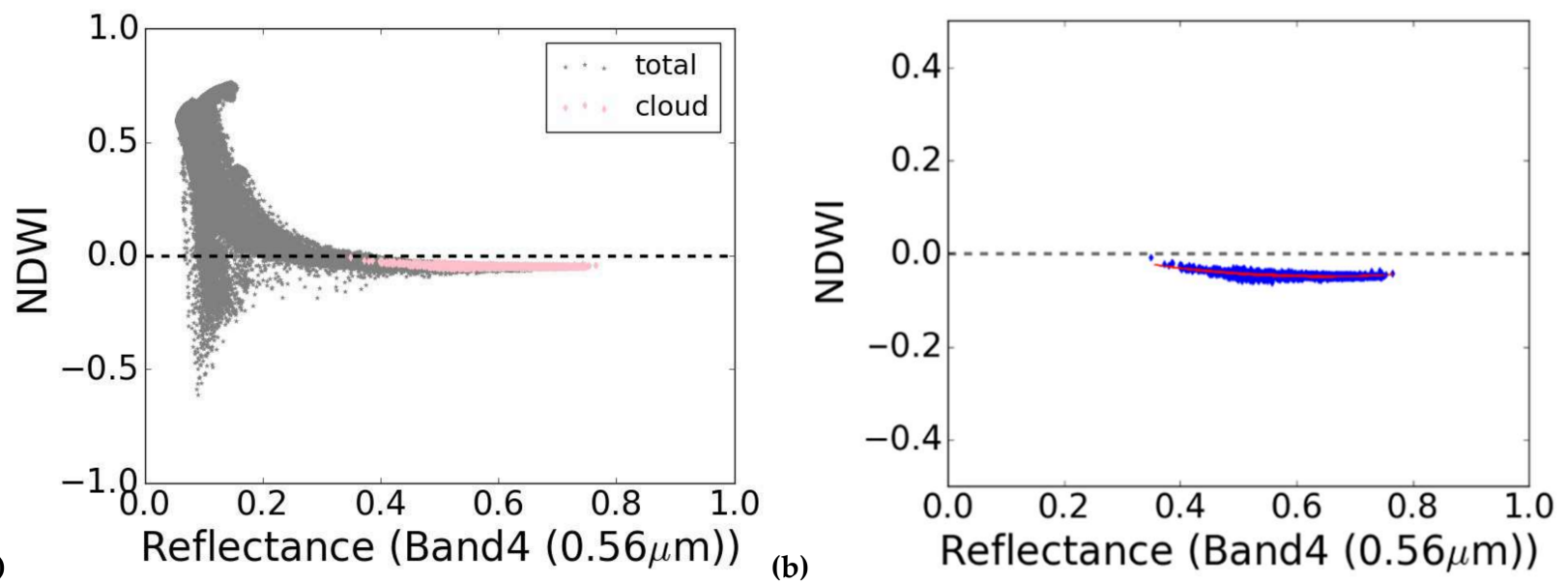

Figure 5. (a) Distribution of cloud pixels and (b) regression relationship between NDWI and MODIS $R_{0.56 \mu \mathrm{m}}$ for cloud pixels on 1 June 2017, 02:15 UTC. The pink pixels in (a) are clouds selected from the RGB image. The grey pixels in (a) denote all MODIS pixels on the same date. Blue pixels in (b) indicate the cloud pixels. The red line in $(\mathbf{b})$ is the regression relationship for cloud pixels.

Figure 6 displays the variation of CC, bias, RMSE, POD-FAR, and HSS values between the MODIS CM and the proposed CM according to variations in threshold values, which were $\sigma_{2}$ for the $1.38 \mu \mathrm{m}$ and $\sigma_{3}$ for the $1.61 \mu \mathrm{m}$ bands. Both of these cases showed concave shapes in CC, HSS, and FOD-FAR values, and convex shapes in RMSE values between the MODIS CM and proposed CM. In this study, we determined values of $\sigma_{2}=0.006$ for the $1.38 \mu \mathrm{m}$ band, and $\sigma_{3}=0.04$ for the $1.61 \mu \mathrm{m}$ band when the bias $=0$.

Figure 7 shows a qualitative comparison of $\mathrm{CM}$ using the proposed cloud-detection method with four case studies: 29 April 2014, 02:20 UTC (spring); 12 June 2015, 02:15 UTC (summer); 4 October 2019, 02:15 UTC (autumn); and 6 January 2016, 02:15 UTC (winter). We applied the regression coefficients $\left(a_{0}=0.079, a_{1}=-0.4\right.$, and $\left.a_{2}=0.312\right)$ and $\sigma=0.0377$, which were obtained from MODIS data on 1 June 2017, 02:15 UTC for all the cases. The first column shows the MODIS RGB images, and the second column displays the results of cloud detection when we applied only the NDWI-green band relationship to our CM algorithm. We can identify that the NDWI-green band relationship was useful for detecting thick clouds but missed parts of thin clouds. The third column shows the results using $R_{1.38 \mu \mathrm{m}}$, 
which detected cirrus clouds. The fourth column displays the results using $R_{1.61 \mu \mathrm{m}}$, which detected most of the thin and high clouds. The fifth column shows the final results of our CM including the NDWI-green band relationship, $R_{1.38 \mu \mathrm{m}}$, and $R_{1.61 \mu \mathrm{m}}$, which detects thin and thick clouds. Consequently, the NDWI-green band relationship in the proposed cloud-detection method detected fewer cloud pixels than the MODIS CM in the Yellow Sea and Bohai Sea because the proposed method excludes semitransparent clouds and optically thick clouds. However, the proposed method based on the combination of NDWI-green band relationship and threshold values of 1.38 and $1.61 \mu \mathrm{m}$ bands was much better at detecting thin clouds than the MODIS CM, as shown in Figure 7. These results demonstrate that the proposed CM requires $0.56 \mu \mathrm{m}, 0.86 \mu \mathrm{m}, 1.38 \mu \mathrm{m}$, and $1.61 \mu \mathrm{m}$ bands for the best detection of clouds.

Figure 8 shows a quantitative comparison of the proposed CM and MODIS CM for four cases: spring (29 April 2014, 02:20 UTC), summer (12 June 2015, 02:15 UTC), autumn (4 October 2019, 02:15 UTC), and winter (6 January 2016, 02:15 UTC). The light cyan color indicates that both CMs detect a pixel as a cloud. The red pixels indicate that only MODIS $\mathrm{CM}$ detects the pixel as a cloud. The green pixels indicate that only the proposed method detects pixels as cloud pixels. Blue indicates the pixels in which both CMs are detected as cloud-free sea surfaces. The tan pixels indicate the land masks. Table 3 summarizes the statistical scores of POD, FAR, and HSS for the four case studies. The POD values were $>0.923$. The overall values of FAR and HSS were $<0.091$ and $>0.835$, respectively. The MODIS CM misidentified sea ice in the Bohai Sea as clouds, while the proposed CM correctly distinguished cloud pixels from sea ice pixels on 6 January 2016, 02:15 UTC.
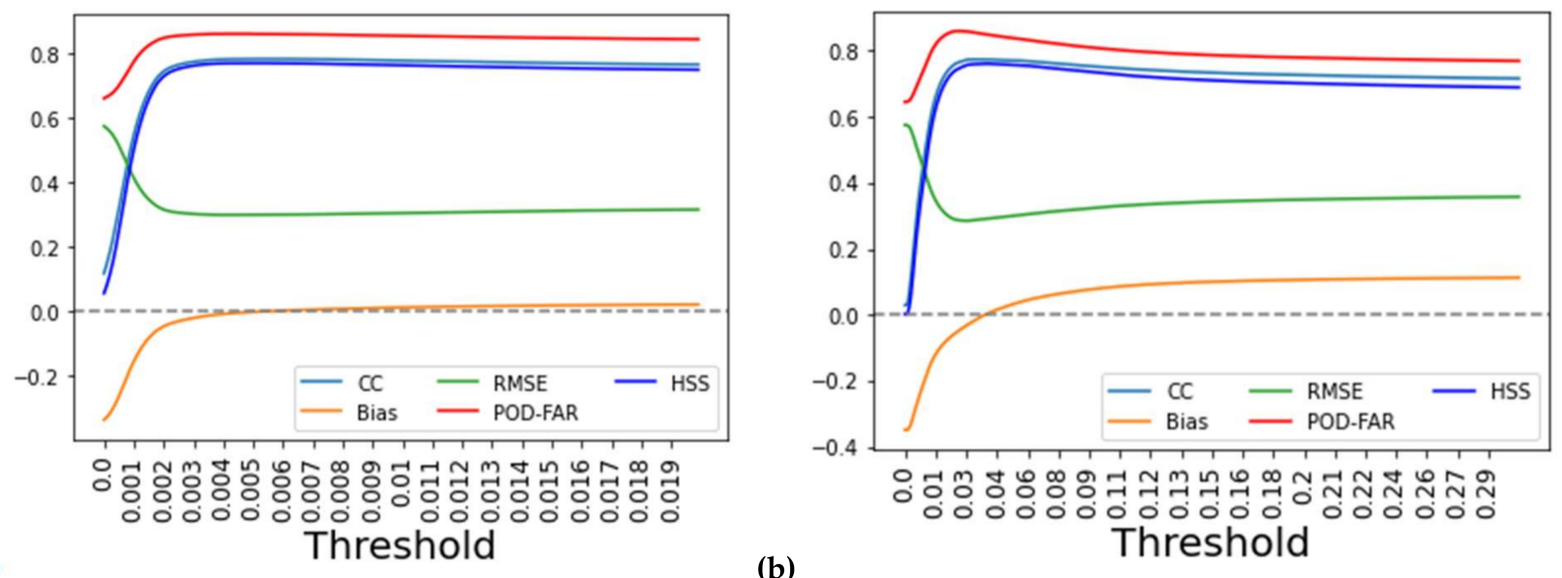

(b)

Figure 6. Threshold value-dependent statistical scores obtained from the comparison between MODIS $\mathrm{CM}$ and the proposed CM for the (a) 1.38 and (b) $1.61 \mu \mathrm{m}$ bands using the test dataset found in the pink box (Figure 2), for 1 June 2017, 02:15 UTC. Cyan, green, yellow, blue, and red lines indicate CC, RMSE, bias, HSS, and POD-FAR values, respectively.

Figure 9 shows the validation results using the MODIS RGB image, MODIS CM, the proposed CM, and the CALIPSO data on 25 March 2020 (spring), 15 July 2020 (summer), 26 September 2020 (autumn), and 16 January 2021 (winter). The observation times between MODIS and CALIPSO differed by 9, 16, 27, and $28 \mathrm{~min}$, respectively. The CALIPSO data with cloud (cyan color) and clear (blue color) flags were delineated by overlaying on the MODIS and the proposed CMs. The validation results with the CALIPSO data for the four cases showed qualitatively good agreement between the MODIS CM and the proposed CM. 


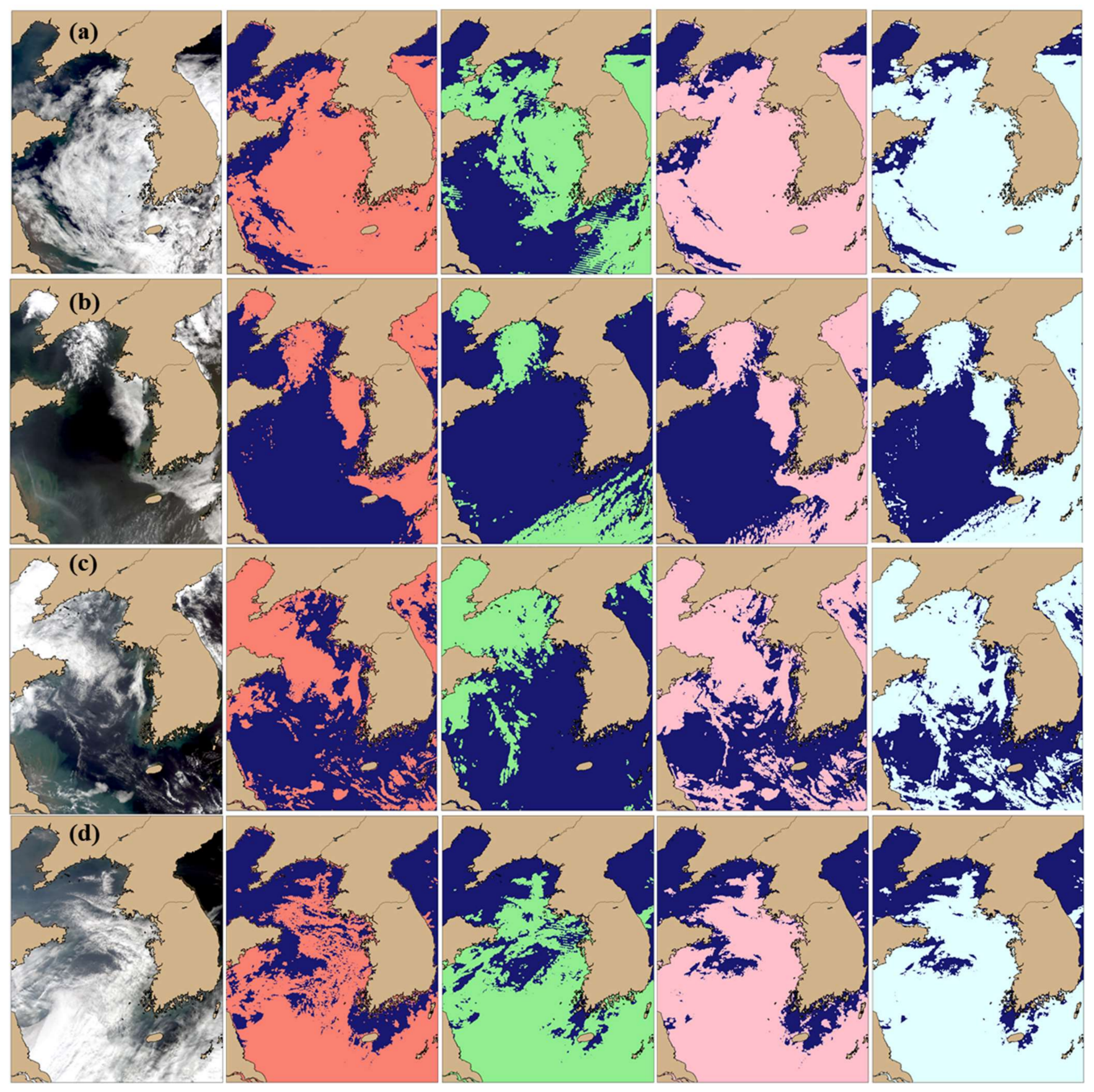

Figure 7. Case studies: (first column) MODIS RGB images, (second column) cloud mask using only NDWI-green band relationship, (third column) cloud mask using only $R_{1.38 \mu \mathrm{m}}$ method, (fourth column) cloud mask using only $R_{1.61 \mu \mathrm{m}}$ method, and (fifth column) cloud mask using the proposed cloud detection method (combination of (b-d)) on (a) 29 April 2014, 02:20 UTC (spring); (b) 12 June 2015 02:15 UTC (summer); (c) 4 October 2019, 02:15 UTC (autumn); and (d) 6 January 2016, 02:15 UTC (winter). 


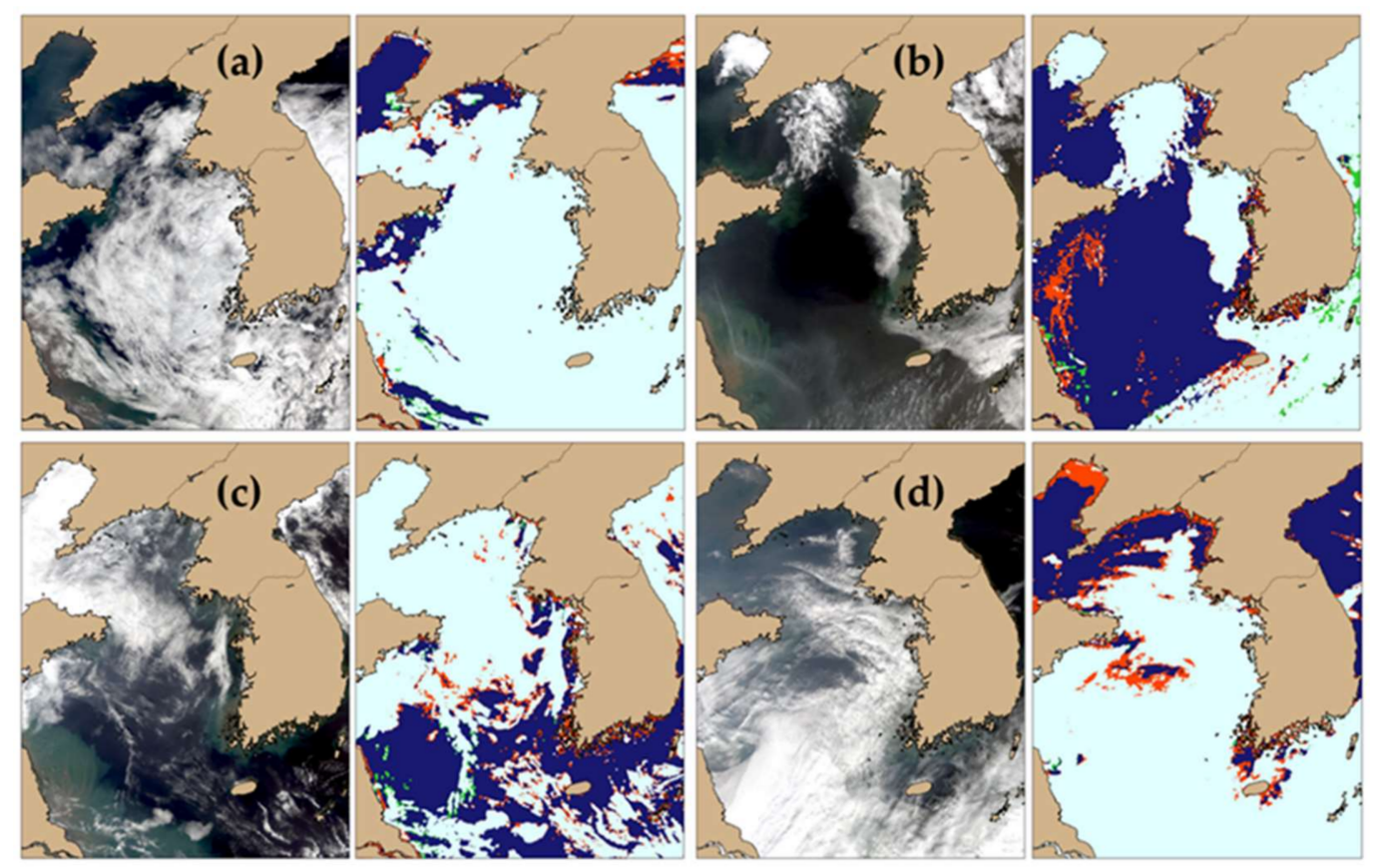

Figure 8. Quantitative comparison of the proposed CM and MODIS CM for the four cases for (a) spring (29 April 2014. 02:20 UTC), (b) summer (12 June 2015, 02:15 UTC), (c) autumn (4 October 2019, 02:15 UTC), and (d) winter (6 January 2016, 02:15 UTC). The light cyan colors indicate that both CMs detected the pixel as a cloud. The red pixels indicate that only MODIS CM detected the pixel as a cloud. The green pixels indicate that only the proposed CM detected the pixel as a cloud pixel. The blue colors indicates that both CMs detected the pixel as cloud-free sea surfaces. Tan colors indicate the land mask.

Table 3. Statistical comparison between the proposed CM and MODIS CM.

\begin{tabular}{cccc}
\hline Case & POD & FAR & HSS \\
\hline 29 April 2014, 02:20 UTC & 0.984 & 0.010 & 0.903 \\
12 June 2015, 02:15 UTC & 0.935 & 0.091 & 0.850 \\
4 October 2019, 02:15 UTC & 0.950 & 0.010 & 0.943 \\
6 January 2016, 02:15 UTC & 0.923 & 0.002 & 0.835 \\
\hline
\end{tabular}

Figure 10 shows the CALIPSO VFM data on 25 March 2020, 05:14 UTC, 15 July 2020, 05:21 UTC, 26 September 2020, 05:27 UTC, and 16 January 2021, 05:28 UTC in Figure 8. We classified the vertical atmospheric and surface features of CALIPSO observations based on the feature classification flags of the CALIPSO VFM data. In the legend for Figure 9, no signal, subsurf, surface, strato, aerosol, cloud, and clear indicate no signal (complete signal attenuation), subsurface, surface, stratospheric aerosol, tropospheric aerosol, cloud, and clear air, respectively. The MODIS CM and the proposed CM were in qualitatively good agreement with the CALIPSO VFM data for the four cases. The statistical scores of POD, FAR, and HSS also show quantitatively consistent results between the MODIS CM and the proposed CM. Table 4 summarizes the validation results using the CALIPSO data in Figure 8, which demonstrates that the proposed CM is consistent with the MODIS CM. 
(a)

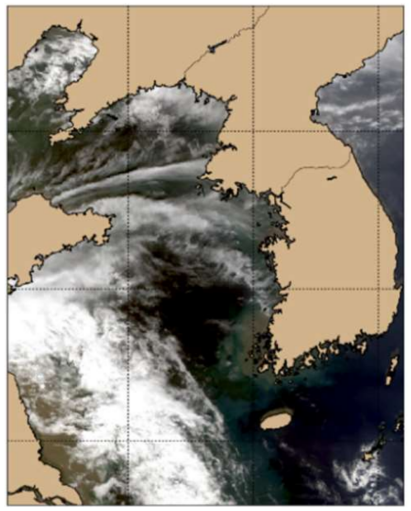

(b)

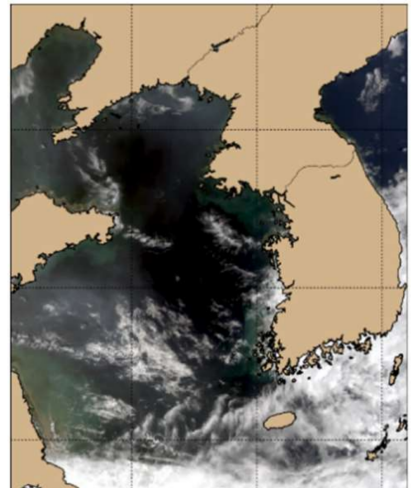

b)

(c)

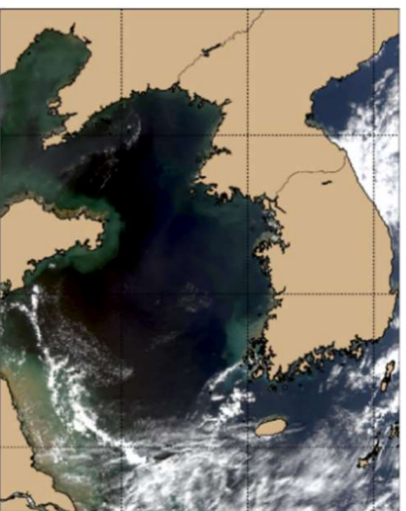

(d)

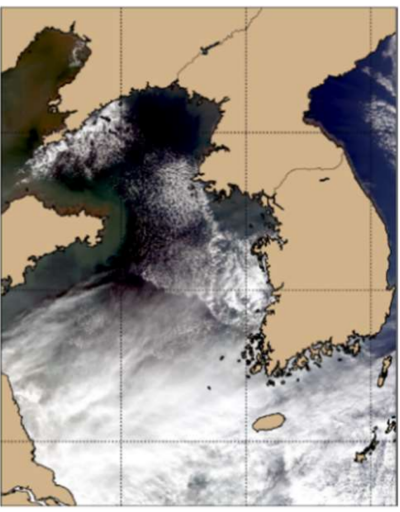

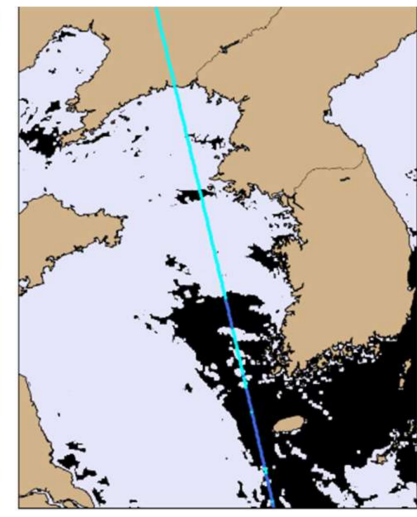
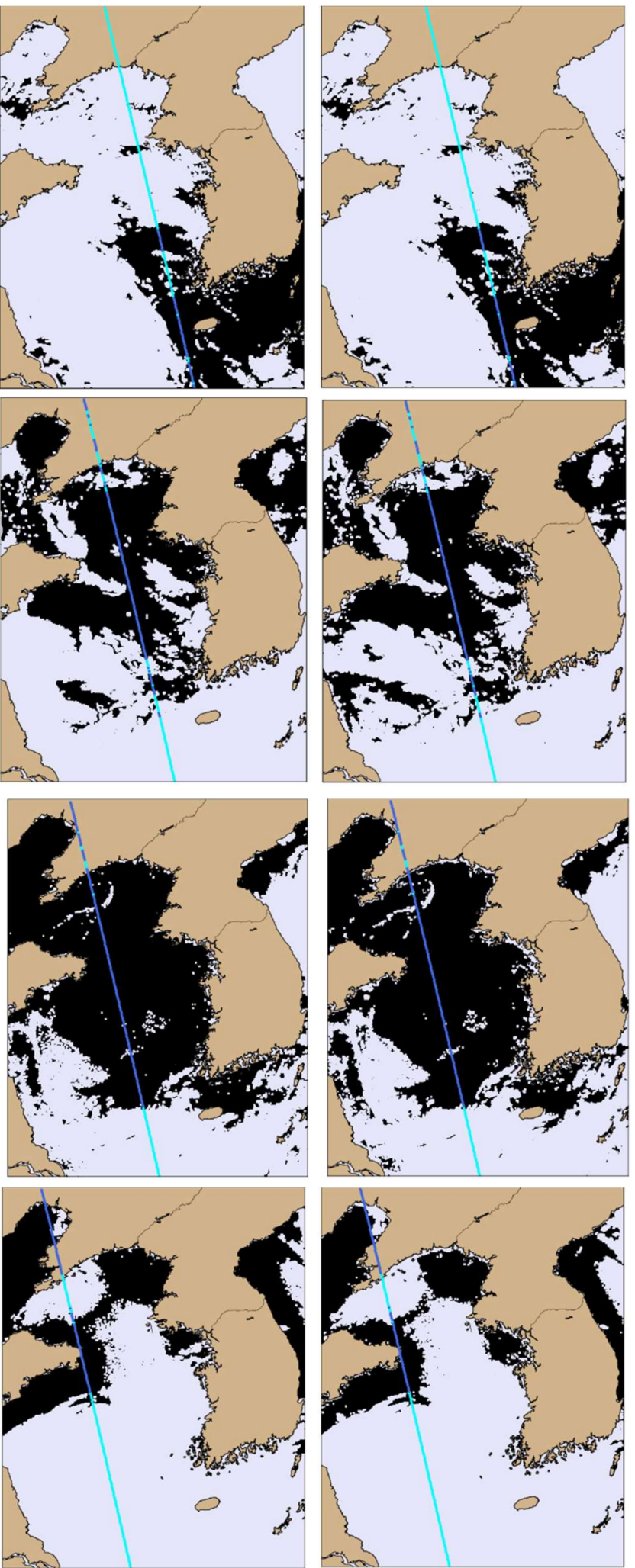

Figure 9. (a) spring case: 25 March 2020 (05:05 UTC (MODIS) and 05:14 UTC (CALIPSO)); (b) summer case: 15 July 2020 (05:05 UTC (MODIS) and 05:21 UTC (CALIPSO)); (c) autumn case: 26 September 2020 (05:00 UTC (MODIS) and 05:27 UTC (CALIPSO)); (d) winter case: 16 January 2021 (05:00 UTC (MODIS) and 05:28 UTC (CALIPSO)). The first, second, and third rows indicate the MODIS RGB image, the proposed CM, and MODIS CM, respectively. CALIPSO laser footprints are overlaid in the second and third columns where cyan and blue colors indicate cloud or no cloud pixels, respectively. 
(a)
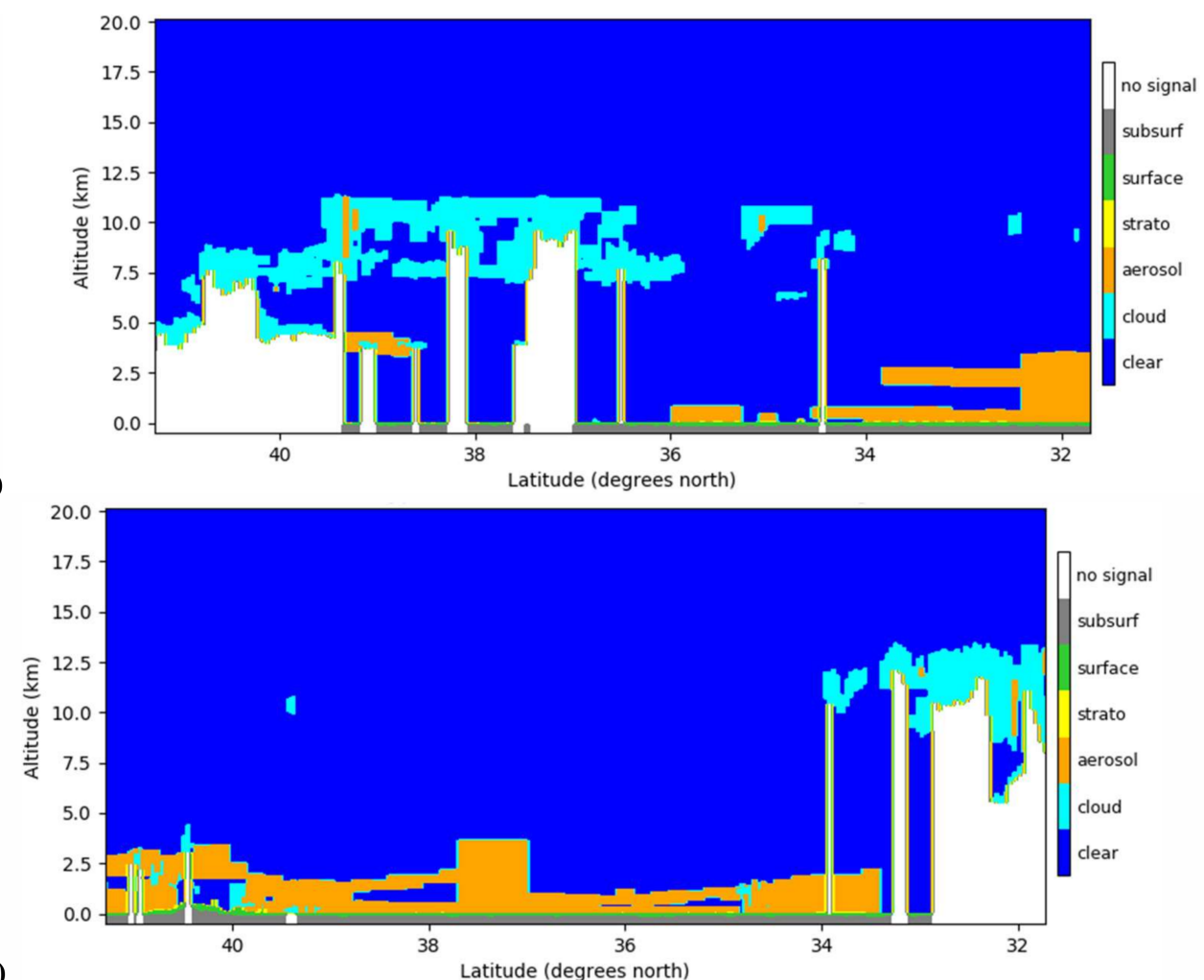

(b)

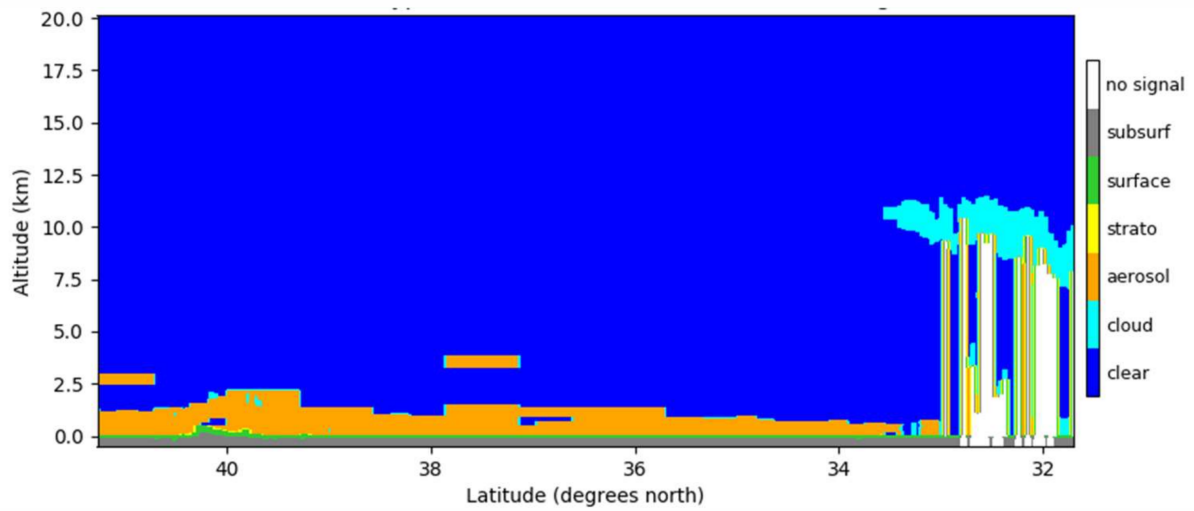

(c)

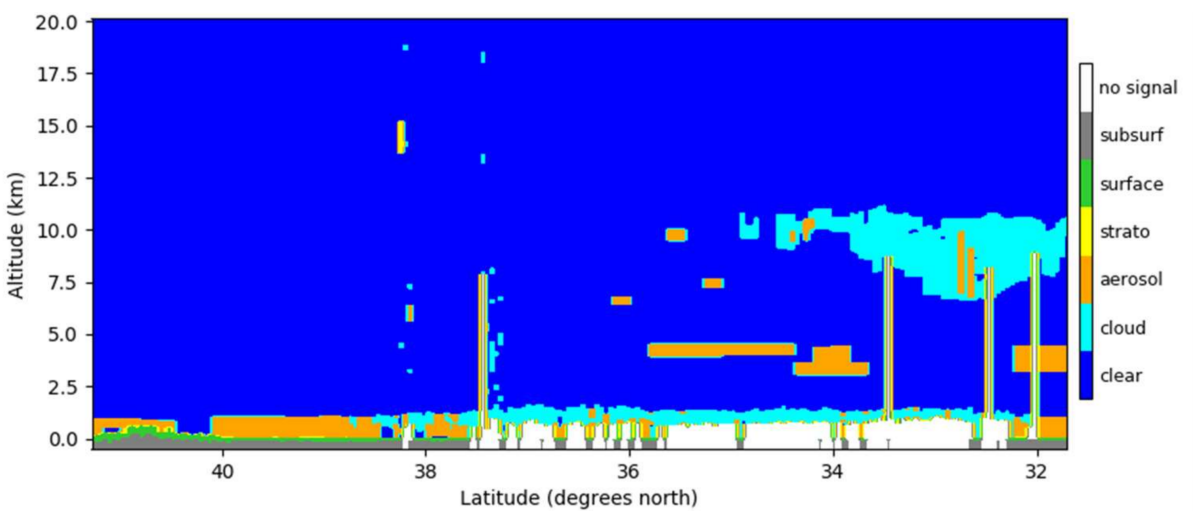

(d)

Figure 10. CALIPSO VFM plots on cases in Figure 8, (a) 25 March 2020 05:14 UTC; (b) 15 July 2020 05:21 UTC; (c) 26 September 2020 05:27 UTC; (d) 16 January 2021 05:28 UTC. The legends of no signal, subsurf, surface, strato, aerosol, cloud, and clear denote no signal (complete signal attenuation), subsurface, surface, stratospheric aerosol, tropospheric aerosol, cloud, and clear air, respectively. 
Table 4. Statistical comparison of the proposed CM and MODIS CM using the CALIPSO data.

\begin{tabular}{ccccccc}
\hline \multirow{2}{*}{ Dates } & \multicolumn{3}{c}{ CALIPSO vs. MODIS CM } & \multicolumn{3}{c}{ CALIPSO vs. Proposed CM } \\
\cline { 2 - 7 } & POD & FAR & HSS & POD & FAR & HSS \\
\hline Spring (25 March 2020) & 0.72 & 0.00 & 0.64 & 0.85 & 0.01 & 0.78 \\
Summer (15 July 2020) & 0.79 & 0.09 & 0.77 & 0.76 & 0.08 & 0.75 \\
Autumn (26 September 2020) & 0.91 & 0.05 & 0.91 & 0.89 & 0.03 & 0.91 \\
Winter (16 January 2021) & 0.97 & 0.06 & 0.70 & 0.97 & 0.02 & 0.84 \\
\hline
\end{tabular}

Figure 11 shows temporal variations of POD, FAR, and HSS between MODIS CM and our CM for the 79 case studies, from 2000 to 2019. The POD and HSS values between MODIS CM and our CM tended to increase. The FAR tended to decrease between the two CMs. Relatively large discrepancies occurred on 20 May 2000, 03:00 UTC; 7 July 2003, 02:50 UTC; 1 January 2004, 02:40 UTC; 29 April 2006, 02:45 UTC; 25 June 2007, 02:45 UTC; 17 October 2008, 02:45 UTC; 27 April 2010 02:15 UTC; and 4 April 2018, 02:45 UTC due to haze or seasonally turbid water in this region. In comparison, the results of the cloud fraction between MODIS, onboard the Aqua satellite, and the Visible Infrared Imaging Radiometer Suite sensor, onboard the Suomi National Polar-orbiting Partnership satellite [48], were similar to ours.

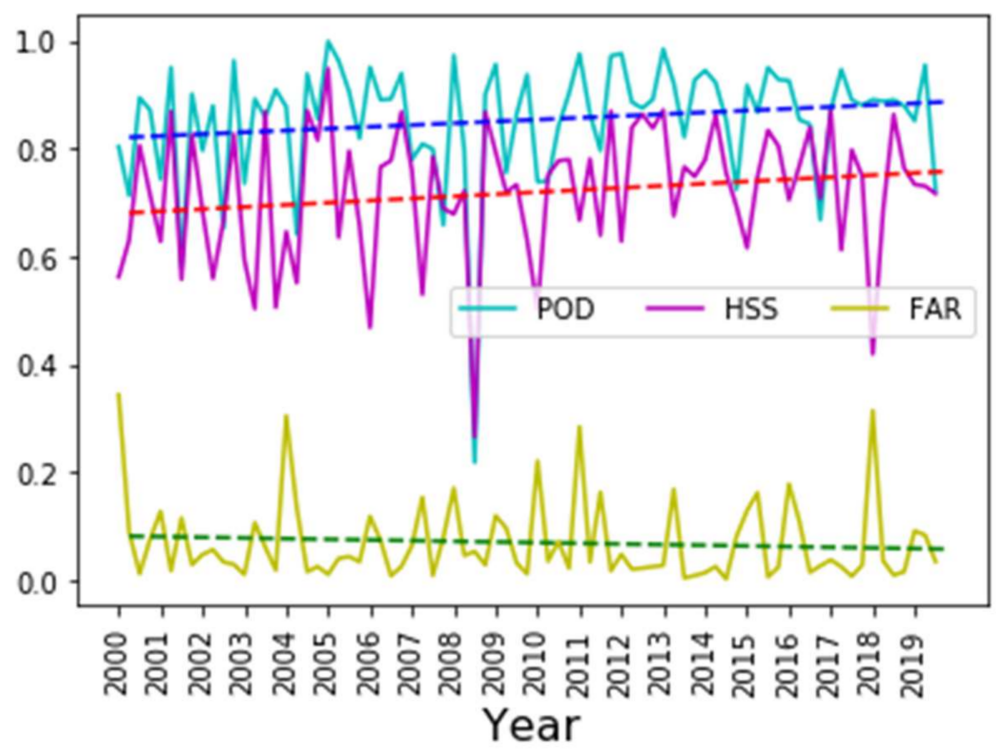

Figure 11. Temporal variations of POD, FAR, and HSS between MODIS CM and our CM from 2000 to 2019 .

\section{Discussion}

The proposed method has the advantage of being able to distinguish sea ice from clouds. Figure 12 shows an example of the qualitative comparison of the proposed $\mathrm{CM}$ and MODIS CM for the particular case of coexistence of clouds and sea ice pixels in MODIS observations on 6 January 2011, 02:25 UTC; 6 January 2016, 02:15 UTC; and 5 January 2018, 02:50 UTC. Clouds over the Yellow Sea are shown in the left column. In this region, the cold air from the Siberian air mass in winter moves southward and meets the relatively warm and humid air over the Yellow Sea and then generates ocean clouds. The proposed method (middle column) delineates the cloud distribution and details of their patterns in the RGB image, while MODIS CM (right column) misidentifies the sea ice over the Bohai Sea as clouds and overestimates the cloud distribution and covers the Yellow Sea. 
(a)

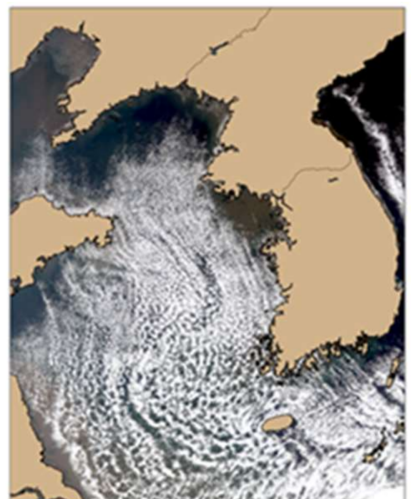

(b)

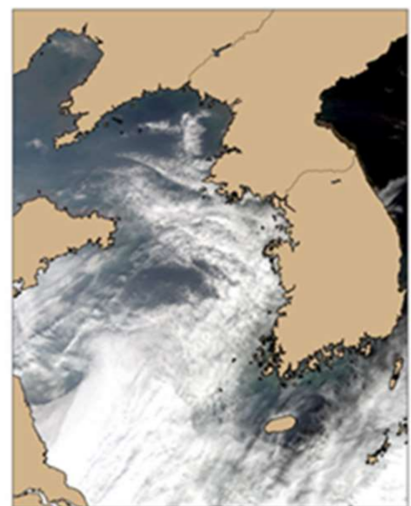

(c)

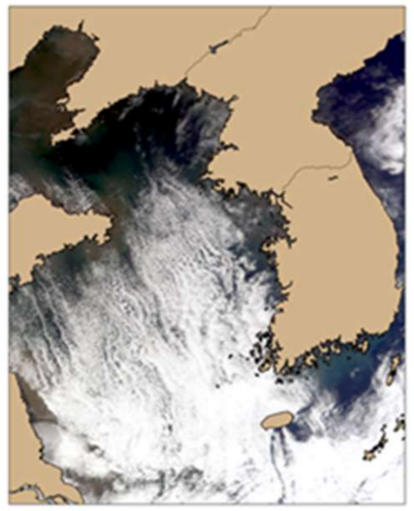

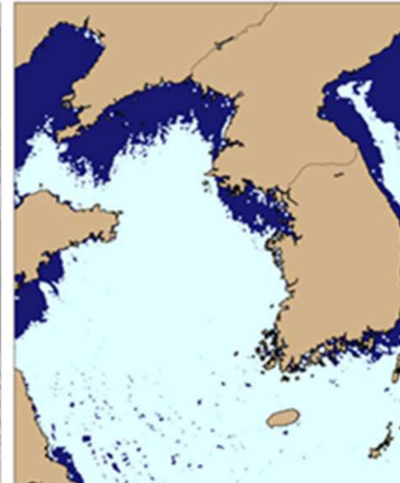
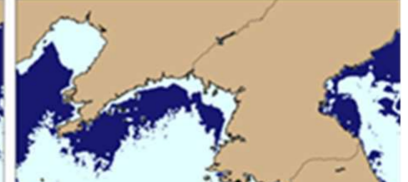

ing

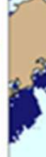

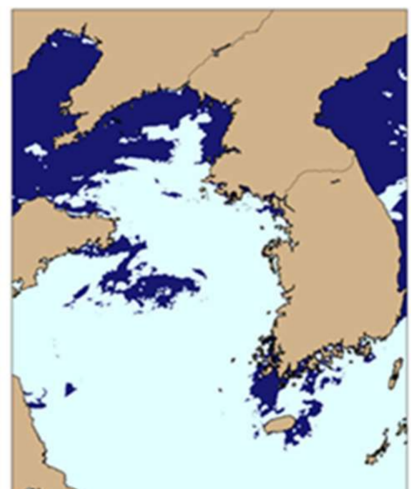
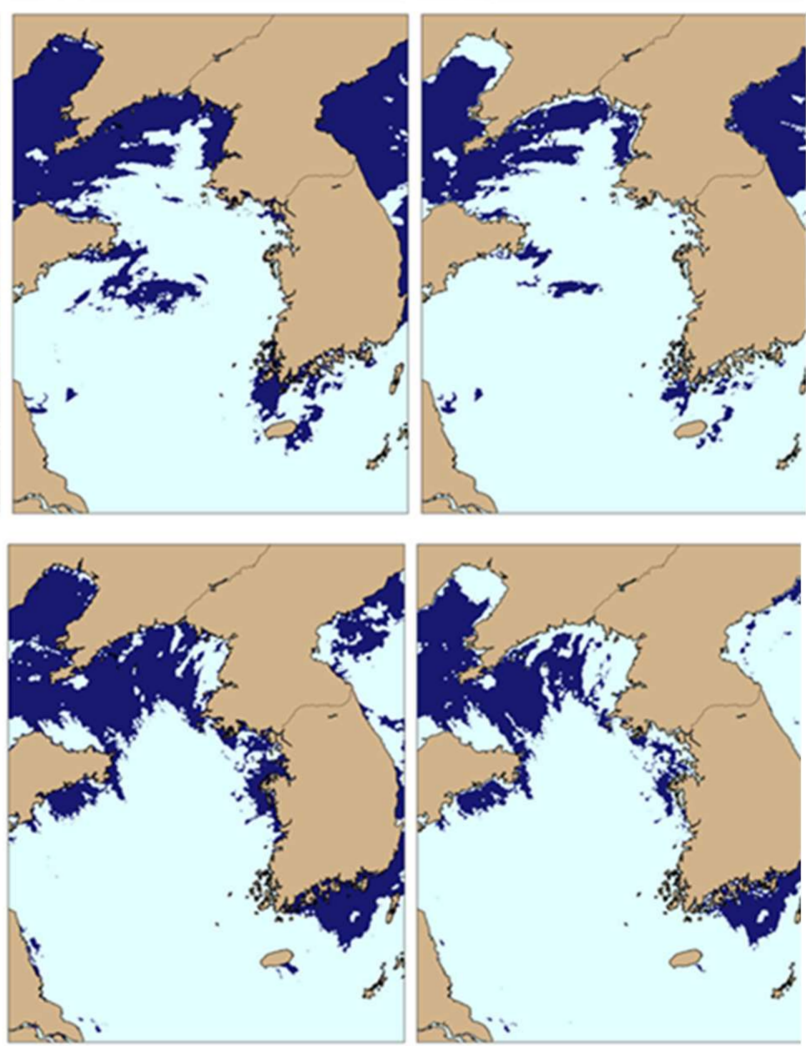

Figure 12. RGB images of a mixture of clouds and sea ice (left column), the proposed CM (middle column), and MODIS CM (right column) on (a) 6 January 2011, 02:25 UTC; (b) 6 January 2016, 02:15 UTC; and (c) 5 January 2018, 02:50 UTC.

The proposed method has the additional advantage of being able to distinguish dust from clouds. Figure 13 shows the particular cases of coexistence of clouds and dust pixels in MODIS observations for 1 April 2001, 02:25 UTC; 8 April 2003, 02:15 UTC; and 16 April 2015, 02:20 UTC. The presence of dust and clouds over the Yellow Sea can be detected in the MODIS RGB images. Here, the yellow dust (Hwang-sa) occurs over the desert areas of China and Mongolia during spring as a unique regional meteorological phenomenon. This yellow dust moved to the east and south over the Yellow Sea and the Korean Peninsula. The proposed method distinguishes dust from clouds, while MODIS CM misidentifies dust over the Bohai Sea as clouds and overestimates the extent distribution of clouds over the Yellow Sea. 
(a)
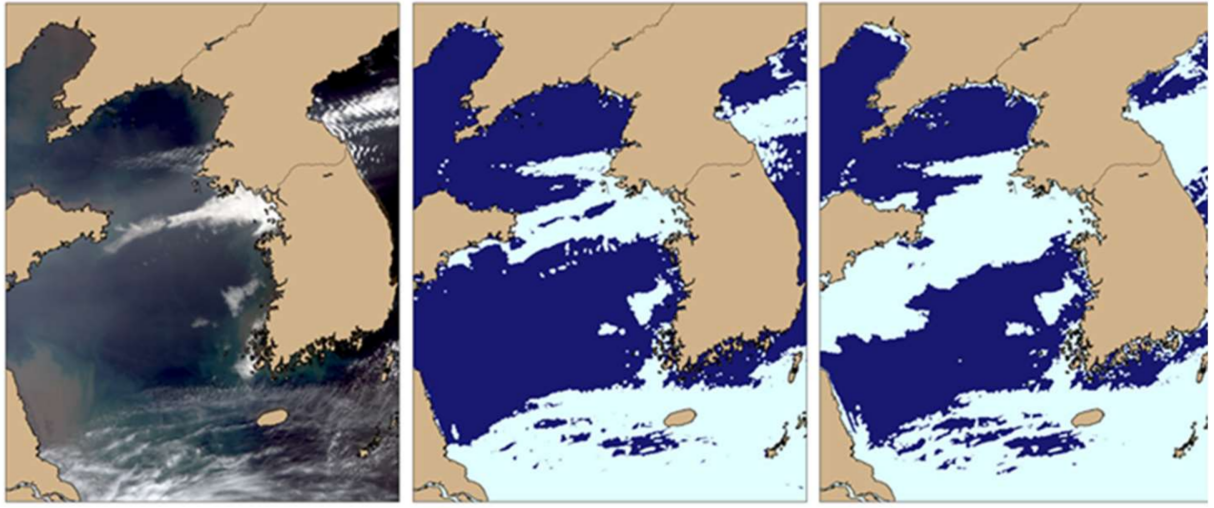

(b)
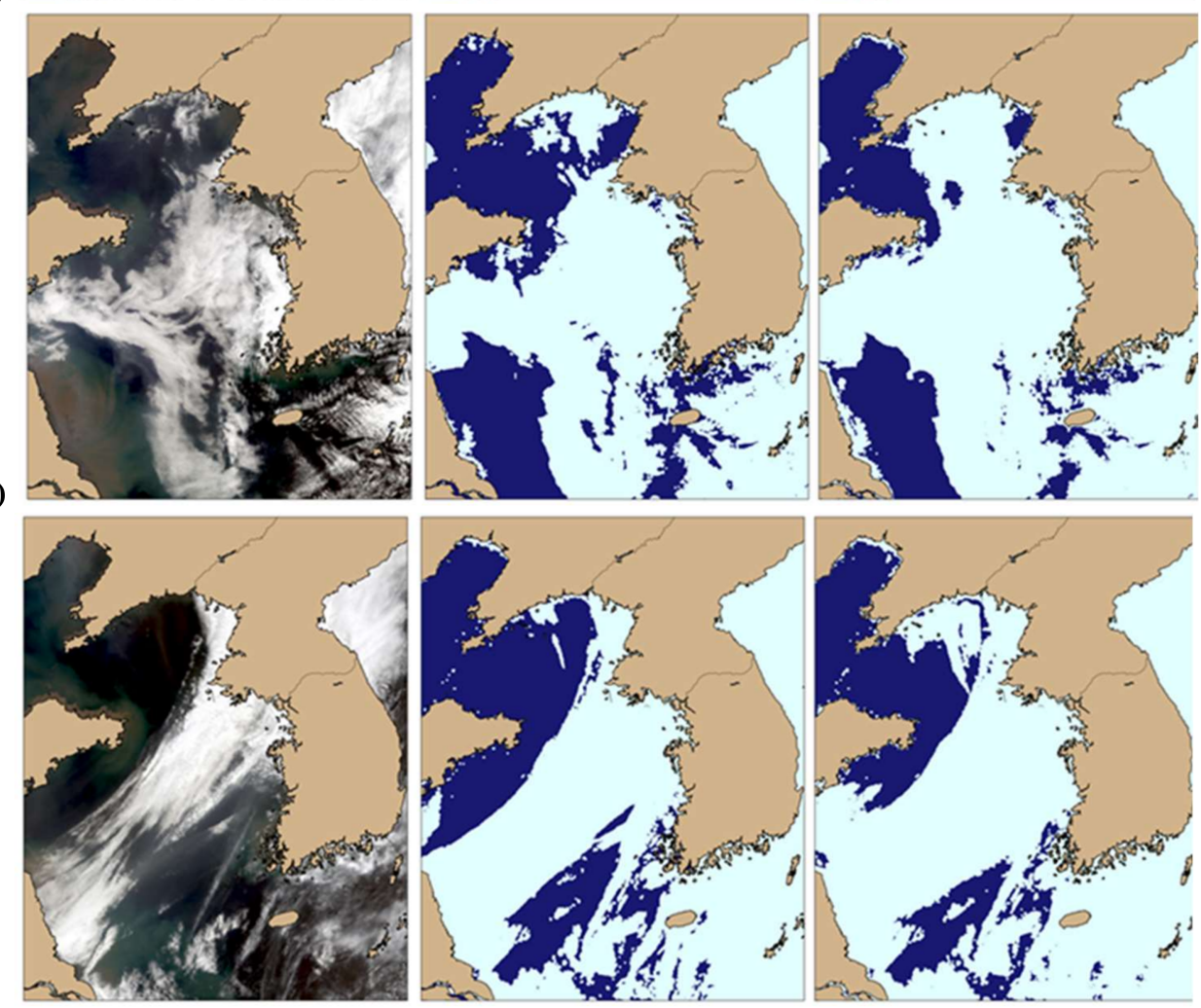

Figure 13. RGB images of a mixture of clouds and dust (left column), the proposed CM (middle column), and MODIS CM (right column) on (a) 2 April 2001, 02:25 UTC; (b) 8 April 2003, 02:15 UTC and (c) 16 April 2015, 02:20 UTC.

\section{Conclusions}

Cloud information plays an important role in weather analysis, climate change, and many other geo-science applications. Currently, satellite remote-sensing is widely used to detect and analyze cloud information. An accurate cloud-masking procedure to distinguish cloud-free pixels from cloud pixels is essential for the unhindered analysis of many parameters on the Earth's surface, such as ocean color study in satellite remote-sensing. Generally, cloud-detection algorithms depend on the spectral characteristics of clouds, such as high reflectance and low temperature in the VIS, NIR, SWIR, and LWIR bands. Generally, split-window measurements, in other words, BTD in IR bands such as $10.8 \mu \mathrm{m}$ and $12.0 \mu \mathrm{m}$ depending on thresholds, have been widely used to detect or mask clouds from satellite observations. In particular, MODIS CM has been widely used because of its long temporal record, wide swath and sampling, and broad spectral range. However, it is well known that the MODIS cloud detection algorithm often misidentifies clouds when sea ice is present. 
Thus, this study proposes a unique cloud-detection method using the relationship between NDWI and reflectance of the green band with the uncertainty of standard deviation in addition to 1.38 and $1.61 \mu \mathrm{m}$ bands for thin cloud detection. Multiple case studies using MODIS observation data were performed for the spring, summer, autumn, and winter seasons from 2000 to 2019 over the Yellow Sea and Bohai Sea. The comparison of the proposed cloud detection method with MODIS CM showed improved performance and detailed cloud information compared to the MODIS CM. For the period 2000-2019, the average POD, FAR, and HSS were $0.853,0.069$, and 0.719 , respectively. Relatively poor statistical results often appear due to the coexistence of clouds and sea ice in the winter and haze or dust in the spring. The time series analysis using the 79 case studies from 2000 to 2019 demonstrated that the POD and HSS values tended to increase, while the FAR values decreased between MODIS CM and our CM. A few cases displayed relatively large discrepancies due to the presence of haze or semitransparent clouds in the scene and seasonally turbid water in the study area. In addition, the proposed cloud-detection method has the advantage of distinguishing cloud pixels from sea ice or yellow dust, which is a difficult problem that the current MODIS CM algorithm cannot mitigate.

Visual inspection of MODIS data indicated the presence of atmospheric cover resembling haze or semitransparent clouds at the location of most case studies. The classification of these pixels as clouds often depends on the user's need for their own atmospheric or sea-surface studies. Currently, the thresholds used in our method for thin clouds have not been optimized. Thus, the proposed approach occasionally identified optically thin clouds, despite visual inspection determining them to be cloud-free. However, these disadvantages may be overcome with additional modification of thresholds and the use of other spectral bands sensitive to various types of clouds according to user needs.

Consequently, the proposed cloud detection method can be applied to a variety of other optical sensors with VIS and NIR bands, such as the Geostationary Ocean Color Imager-II from 0.38 to $0.86 \mu \mathrm{m}$ bands onboard the GEO-KOMPSAT-2B satellite combined with the Advanced Meteorological Imager with 1.38 and $1.61 \mu \mathrm{m}$ bands onboard the GEOKOMPSAT-2A satellite collocated with the GEO-KOMPSAT-2B satellite over the Equator at $128^{\circ} \mathrm{E}$ longitude.

Author Contributions: Conceptualization, S.H.; methodology, Y.-J.C., H.-J.B. and S.H.; software, Y.-J.C. and H.-J.B.; validation, Y.-J.C., H.-J.B. and S.H.; formal analysis, Y.-J.C., H.-J.B., H.-J.H. and S.H.; investigation, Y.-J.C., H.-J.B. and S.H.; resources, S.H.; data curation, Y.-J.C., H.-J.B., H.-J.H. and S.H.; writing—original draft preparation, S.H., Y.J.C. and H.-J.B.; writing-review and editing, S.H.; visualization, Y.-J.C., H.-J.B. and S.H.; supervision, S.H.; project administration, S.H. and H.-J.H.; funding acquisition, S.H. and H.J.H. All authors have read and agreed to the published version of the manuscript.

Funding: This research was supported by the "Development of the integrated data processing system for GOCI-II" (Grant. 1525008614) and "Technology development for Practical Applications of MultiSatellite data to maritime issues" (Grant. 1525012023) funded by the Ministry of Ocean and Fisheries, Republic of Korea.

Data Availability Statement: Not applicable.

Acknowledgments: Y.-J. Choi, H.-J. Ban, H.-J. Han, and S. Hong thank the anonymous reviewers for their helpful and constructive comments on the manuscript.

Conflicts of Interest: The authors declare no conflict of interest.

\section{References}

1. Stowe, L.; Vemury, S.; Rao, A. AVHRR clear-sky radiation data sets at NOAA/NESDIS. Adv. Space Res. 1994, 14, 113-116. [CrossRef]

2. Xiang, H.-B.; Liu, J.-S.; Cao, C.-X.; Xuet, M. Algorithms for Moderate Resolution Imaging Spectroradiometer cloud-free image compositing. J. Appl. Remote Sens. 2013, 7, 073486. [CrossRef]

3. Qiu, B.; Li, W.; Zhong, M.; Tang, Z.; Chen, C. Spatiotemporal analysis of vegetation variability and its relationship with climate change in China. Geo-Spat. Inform. Sci. 2014, 17, 170-180. [CrossRef] 
4. Zeng, Y.; Huang, W.; Zhan, F.B.; Zhang, H.; Liu, H. Study on the urban heat island effects and its relationship with surface biophysical characteristics using MODIS imageries. Geo-Spat. Inform. Sci. 2010, 13, 1-7. [CrossRef]

5. Robinson, W.; Franz, B.A.; Frederick, S.P.; Bailey, S.; Werdell, J. Masks and flags updates. Algorithm updates for the fourth Sea-WiFS data reprocessing. NASA Tech. Memoran. 2003, 206892, 34-40.

6. Wang, M.; Shi, W. Estimation of ocean contribution at the MODIS near-infrared wavelengths along the east coast of the US: Two case studies. Geophys. Res. Lett. 2005, 32, L13606. [CrossRef]

7. Song, X.; Liu, Z.; Zhao, Y. Cloud detection and analysis of MODIS image. In Proceedings of the 2004 IEEE International Geoscience and Remote Sensing Symposium, Anchorage, AL, USA, 20-24 September 2004.

8. Saunders, R.W.; Kriebel, K.T. An improved method for detecting clear sky and cloudy radiances from AVHRR data. Int. J. Remote Sens. 1988, 9, 123-150. [CrossRef]

9. Zhu, Z.; Woodcock, C.E. Automated cloud, cloud shadow, and snow detection in multitemporal Landsat data: An algorithm designed specifically for monitoring land cover change. Remote Sens. Environ. 2014, 152, 217-234. [CrossRef]

10. Ackerman, S.A.; Frey, R. MODIS Atmosphere L2 Cloud Mask Product (35_L2). NASA MODIS Adaptive Processing System, Goddard Space Flight Center, USA, 2015. Available online: https://modaps.modaps.eosdis.nasa.gov/services/about/products/ c6/MOD35_L2.html (accessed on 23 September 2019). [CrossRef]

11. Kraatz, S.; Khanbilvardi, R.; Romanov, P. A Comparison of MODIS/VIIRS Cloud Masks over Ice-Bearing River: On achieving consistent cloud masking and improved river ice mapping. Remote Sens. 2017, 9, 229. [CrossRef]

12. Dorofy, P.; Nazari, R.; And, P.R.; Key, J. Development of a Mid-Infrared Sea and Lake Ice Index (MISI) using the GOES imager. Remote Sens. 2016, 8, 1015. [CrossRef]

13. Chaouch, N.; Temimi, M.; Romanov, P.; Cabrera, R.; McKillop, G.; Khanbilvardi, R. An automated algorithm for river ice monitoring over the Susquehanna River using the MODIS data. Hydrol. Process. 2014, 28, 62-73. [CrossRef]

14. Liu, H.; Zeng, D.; Tian, Q. Super-pixel cloud detection using hierarchical fusion CNN. In Proceedings of the 2018 IEEE Fourth International Conference on Multimedia Big Data (BigMM), Xi'an, China, 13-16 September 2018.

15. Bulgin, C.E.; Mittaz, J.P.; Embury, O.; Eastwood, S.; Merchant, C.J. Bayesian cloud detection for 37 years of advanced very high resolution radiometer (AVHRR) global area coverage (GAC) data. Remote Sens. 2018, 10, 97. [CrossRef]

16. Tan, K.; Zhang, Y.; Tong, X. Cloud extraction from Chinese high resolution satellite imagery by probabilistic latent semantic analysis and object-based machine learning. Remote Sens. 2016, 8, 963. [CrossRef]

17. Fu, H.; Shen, Y.; Liu, J.; He, G.; Chen, J.; Liu, P.; Qian, J.; Li, J. Cloud detection for FY meteorology satellite based on ensemble thresholds and random forests approach. Remote Sens. 2019, 11, 44. [CrossRef]

18. Ghosh, R.R.; Ali, M.S.; Hena, A.; Rahman, H. A simple cloud detection algorithm using NOAA-AVHRR satellite data. Int. J. Sci. Eng. Res. 2012, 3, 1-5.

19. Li, C.; Ma, J.; Yang, P.; Li, Z. Detection of cloud cover using dynamic thresholds and radiative transfer models from the polarization satellite image. J. Quant. Spectrosc. Radiat. Transf. 2019, 222, 196-214. [CrossRef]

20. Hagolle, O.; Huc, M.; Pascual, D.V.; Dedieu, G. A multi-temporal method for cloud detection, applied to FORMOSAT-2, VEN $\mu$, LANDSAT and SENTINEL-2 images. Remote Sens. Environ. 2010, 114, 1747-1755. [CrossRef]

21. Zhu, Z.; Wang, S.; Woodcock, C.E. Improvement and expansion of the Fmask algorithm: Cloud, cloud shadow, and snow detection for Landsats 4-7, 8, and Sentinel 2 images. Remote Sens. Environ. 2015, 159, 269-277. [CrossRef]

22. Murino, L.; Amato, U.; Carfora, M.F. Cloud detection of MODIS multispectral images. J. Atmos. Ocean. Technol. 2014, 31, 347-365. [CrossRef]

23. Sun, L.; Mi, X.; Wei, J.; Wang, J.; Tian, X.; Yu, H.; Gan, P. A cloud detection algorithm-generating method for remote sensing data at visible to short-wave infrared wavelengths. ISPRS J. Photogramm. Remote Sens. 2017, 124, 70-88. [CrossRef]

24. Stephens, G.L.; Vane, D.G.; Boain, R.J.; Mace, G.G.; Sassen, K.; Wang, Z.; Illingworth, A.J.; O'Connor, E.J.; Rossow, W.B.; Durden, S.L.; et al. The CloudSat mission and the A-Train: A new dimension of space-based observations of clouds and precipitation. Bull. Amer. Meteor. Soc. 2002, 83, 1771-1790. [CrossRef]

25. Mao, F.; Duan, M.; Min, Q.; Gong, W.; Pan, Z.; Liu, G. Investigating the impact of haze on MODIS cloud detection. J. Geophy. Res. 2015, 120, 12237-12247. [CrossRef]

26. Lee, K.H. 3-D perspectives of atmospheric aerosol optical properties over Northeast Asia using LIDAR on-board the CALIPSO satellite. Korean J. Remote Sens. 2014, 30, 559-570. [CrossRef]

27. Platnick, S.; King, M.D.; Ackerman, S.A.; Menzel, W.P.; Baum, B.A.; Riédi, J.C.; Frey, R.A. The MODIS cloud products: Algorithms and examples from Terra. IEEE Trans. Geosci. Remote Sens. 2003, 41, 459-473. [CrossRef]

28. Remer, L.A.; Kaufman, Y.; Tanré, D.; Mattoo, S.; Chu, D.; Martins, J.V.; Li, R.-R.; Ichoku, C.; Levy, R.C.; Kleidman, R.G.; et al. The MODIS aerosol algorithm, products, and validation. J. Atmos. Sci. 2005, 62, 947-973. [CrossRef]

29. Ackerman, S.; Frey, R.; Strabala, K.; Liu, Y.; Gumley, L.; Baum, B.; Menzel, P. Discriminating Clear-Sky from Cloud with MODIS-Algorithm Theoretical Basis Document (MOD35). Products (MOD35). ATBD-MOD-06, 2010, 6.1, 121. Available online: http:/ / modis-atmos.gsfc.nasa.gov/_docs/MOD35_ATBD_Collection6.pdf (accessed on 23 September 2019).

30. Strabala, K. MODIS Cloud Mask User's Guide. Available online: http:/ / cimss.ssec.wisc.edu/modis/CMUSERSGUIDE.PDF (accessed on 23 August 2019).

31. Frey, R.A.; Ackerman, S.A.; Liu, Y.; Strabala, K.I.; Zhang, H.; Key, J.R.; Wang, X. Cloud detection with MODIS. Part I: Improvements in the MODIS cloud mask for collection 5. J. Atmos. Ocean. Technol. 2008, 25, 1057-1072. [CrossRef] 
32. Ackerman, S.A.; Strabala, K.I.; Menzel, W.P.; Frey, R.A.; Moeller, C.C.; Gumley, L.E. Discriminating clear sky from clouds with MODIS. J. Geophys. Res. 1998, 103, 32141-32157. [CrossRef]

33. Ackerman, S.; Holz, R.; Frey, R.; Eloranta, E.; Maddux, B.; McGill, M. Cloud detection with MODIS. Part II: Validation. J. Atmos. Ocean. Technol. 2008, 25, 1073-1086. [CrossRef]

34. Thompson, J.A.; Paull, D.J.; Lees, B.G. An improved liberal cloud-mask for addressing snow/cloud confusion with MODIS. Photogramm. Eng. Remote Sens. 2015, 81, 119-129.

35. Muhammad, P.; Duguay, C.; Kang, K.K. Monitoring ice break-up on the Mackenzie River using MODIS data. Cryosphere 2016, 10, 569. [CrossRef]

36. Riggs, G.A.; Hall, D.K.; Ackerman, S.A. Sea ice extent and classification mapping with the Moderate Resolution Imaging Spectroradiometer Airborne Simulator. Remote Sens. Environ. 1999, 68, 152-163. [CrossRef]

37. McFeeters, S.K. The use of the Normalized Difference Water Index (NDWI) in the delineation of open water features. Int. J. Remote Sens. 1996, 17, 1425-1432. [CrossRef]

38. Gao, B.-C. NDWI-A normalized difference water index for remote sensing of vegetation liquid water from space. Remote Sens. Environ. 1996, 58, 257-266. [CrossRef]

39. Rogers, A.; Kearney, M. Reducing signature variability in unmixing coastal marsh Thematic Mapper scenes using spectral indices Int. J. Remote Sens. 2004, 25, 2317-2335. [CrossRef]

40. Gao, B.-C.; Kaufman, Y.J. Selection of the 1.375- $\mu \mathrm{m}$ MODIS channel for remote sensing of cirrus clouds and stratospheric aerosols from space. J. Atmos. Sci. 1995, 52, 4231-4237. [CrossRef]

41. Gao, B.-C.; Li, R.-R. Removal of thin cirrus scattering effects in Landsat 8 OLI images using the cirrus detecting channel. Remote Sens. 2017, 9, 834. [CrossRef]

42. Meyer, K.; Yang, P.; Gao, B.-C. Optical thickness of tropical cirrus clouds derived from the MODIS $0.66 \mathrm{and} 1.375-/ \mathrm{spl} \mathrm{mu/m}$ channels. IEEE Trans. Geosci. Remote Sens. 2004, 42, 833-841. [CrossRef]

43. Meyer, K.; Yang, P.; Gao, B.-C. Ice cloud optical depth from MODIS cirrus reflectance. IEEE Geosci. Remote Sen. Lett. 2007, 4 , 471-474. [CrossRef]

44. Gao, B.C.; Kaufman, Y.J.; Han, W.; Wiscombe, W.J. Corection of thin cirrus path radiances in the $0.4-1.0 \mu \mathrm{m}$ spectral region using the sensitive $1.375 \mu \mathrm{m}$ cirrus detecting channel. J. Geophys. Res. 1998, 103, 32169-32176. [CrossRef]

45. Gao, B.-C.; Yang, P.; Han, W.; Li, R.-R.; Wiscombe, W.J. An algorithm using visible and 1.38-/spl mu/m channels to retrieve cirrus cloud reflectances from aircraft and satellite data. IEEE Trans. Geosci. Remote Sens. 2002, 40, 1659-1668.

46. Meyer, K.; Platnick, S. Utilizing the MODIS $1.38 \mu \mathrm{m}$ channel for cirrus cloud optical thickness retrievals: Algorithm and retrieval uncertainties. J. Geophys. Res. 2010, 115, D24209. [CrossRef]

47. Wilks, D.S. Statistical Methods in the Atmospheric Sciences; Academic Press: Oxford, UK, 2011.

48. Frey, R.A.; Ackerman, S.A.; Holz, R.E.; Dutcher, S.; Griffith, Z. The continuity MODIS-VIIRS cloud mask. Remote Sens. 2020, 12, 3334. [CrossRef] 